\title{
Research on the Talent Training Mechanism of Financial Management in Colleges and Universities Under "Internet + "
}

\author{
Manping Weng ${ }^{1}$ Dongdong Weng, ${ }^{2, *}$
}

\author{
${ }^{1}$ Liming Vocational University, Fujian, Quanzhou, China \\ ${ }^{2}$ Xiamen Institute of Technology, Fujian, Xiamen, China \\ *Corresponding author. Email: weng28911985@163.com
}

\begin{abstract}
This paper analyses the problems existing in the training process of financial management professionals, and puts forward suggestions for establishing an interactive linkage mechanism inside and outside the school, innovating the "Internet $+"$ learning concept, optimizing resource allocation, and improving the effectiveness of off-campus internships. Hopefully these suggestions can be optimized. The training mode of financial management professionals improves the employment rate and satisfaction of financial management professionals.
\end{abstract}

Keywords: Internet+, Training mode, Corresponding countermeasures.

1. "INTERNET +" FINANCIAL MANAGEMENT PROFESSIONAL TALENT TRAINING MODE ANALYSIS

\subsection{Unreasonable Management System Inside and Outside the School}

Under the current circumstances, there are irrationalities in the management systems of some schools, which lead to unsatisfactory teaching effects. The main reasons are as follows:

First of all, students have class teachers on campus and instructors during off-campus internships. If the division of labor between teachers is not clear, in addition, due to the time and space constraints of oncampus learning and off-campus internships, teachers' lesson preparation and classroom teaching cannot be coordinated and unified, which may occur. There are two situations of duplication of teaching content and omission of teaching content [1-3].

Secondly, in recent years, there have not been enough internship positions outside the school, which has caused a lot of trouble for students majoring in financial management. However, practical training is a major link before graduates' step into the society. As a result, some students cannot find suitable internship positions and can only go to some factories to engage in work that is not related to their major, just to get an internship certificate. This practice of falsification has completely deviated from the school's educational goals and prevented students' vocational skills from being improved.

Finally, the convenience of the Internet is a "doubleedged sword". Although it brings learning opportunities to students majoring in financial management, it also makes some students who are not self-controlling deep in the virtual world and cannot focus on their studies. When teaching online [4-5], students often do things in private that are not related to learning.

\subsection{Inadequate Understanding of "Internet+"}

Students of financial management teaching do not know much about "Internet+". A large part of the reason is that they use computers less frequently before entering university, and the computer classes at the middle and high school stages generally only teach some basic computer knowledge. Will not lead students to involve in the deeper areas of the Internet. Therefore, this has led to the current college financial management students unable to embrace the "Internet + " era.

From the perspective of teachers' professional quality, some old teachers who have been teaching for a long time cannot keep up with the pace of the times, are reluctant to accept new things, have a resistance to 
Internet teaching, and stubbornly adhere to traditional teaching methods. This kind of stereotyped educational concept makes students lose some opportunities to use the Internet to learn, and even more unable to stimulate students' interest in learning, so their learning ability has stagnated.

\subsection{Insufficient Utilization of the School Network Construction Resources}

The current campus network construction has not been fully utilized, which is reflected in the students' own situation, business needs and professional skills development. Some young teachers began to use online teaching, and posted and checked homework on the online platform, but this is the basic thing. The actual financial management operating system that is really helpful to students is rarely used, which prevents students from understanding and entering the first time. What kind of challenges they will face in financial management positions after society cannot let them grasp their own actual situation with uneven learning status [6-7]. What's more, some well-behaved teachers resist using the Internet to teach, so that students can't get good development.

\subsection{Unreasonable Arrangements for Off- campus Internships}

Currently, financial management majors in colleges and universities do not closely integrate professional learning with Internet teaching. Students are not proficient in financial management software, and there is a disconnect between their own knowledge and actual operations. The training venues provided by the school for students do not highlight the professional characteristics and the time is relatively short. Most of the off-campus internships arranged are just routine visits, not only do not involve actual operations, some are not related to the financial management major, but just go through the scene. If things go on like this, the accumulated problems will become more and more difficult to remedy [8-9]. The unreasonable use of oncampus resources and the unreasonable arrangements for off-campus internships are also the main reasons why the employment rate of financial management students in colleges and universities in my country has been difficult to increase every year.

\section{2. "INTERNET +" FINANCIAL MANAGEMENT PERSONNEL TRAINING MECHANISM}

\subsection{Establish Interactive Linkage Mechanism Inside and Outside the School}

In response to the problems of the internal and external management system, the author proposed to combine the market industry with the school's training objectives, through the combination of production, education and research, and learn from each other's strengths, so that financial management accounting students can be organically taught in the theoretical teaching and off-campus practical teaching in the context of the Internet. Combine to form an effective interactive linkage mechanism. The "Internet" allows knowledge transfer to break the boundaries of space and time, so that students at school can also understand the needs of off-campus companies and understand the specific work content of the major. Colleges and universities can set up "dual-teacher" classrooms, so that some experienced corporate financial management accountants can explain professional knowledge to students through the "Internet", and display their work content from time to time to convey industry information. Even if students are in school, have never been in contact with companies, and do not understand the actual needs of their positions, they can still learn about updated industry information and professional knowledge under the classroom teaching of teachers outside the school by connecting to the "Internet". It also makes it more convenient and efficient for students to enter the company for field study and visit, saving the human and material costs of student learning and business management. In the "Internet" era, colleges and universities, according to the economic situation and corporate requirements, combine job requirements with school training goals, and develop online classrooms for off-campus teachers of financial management accounting, which can continuously improve the development level and innovative ability of financial management accounting professional education. At the same time, this kind of employment-oriented teaching method is more practical.

\section{2. "Internet +" Learning Concept}

Through innovating the "Internet+" learning concept, we can promote a new school-running model, so that teachers and students can have a deeper understanding of "Internet+" and realize the relationship between "Internet+" and financial management professional teaching. Later, by encouraging teachers to use Internet resources for paperless teaching, the "Internet + " learning concept can penetrate the hearts of teachers and students.

The Internet era puts forward higher requirements for financial management professionals, and more and more companies implement financial management information systems. This requires financial management practitioners not only to master financial accounting knowledge, but also to master some network information management aspects. knowledge. So, when the school is cultivating financial management professionals, it should also start from this aspect, 
offering basic computer application courses and accounting computerization courses, and at the same time, it can also publish the practical teaching and teaching of some industry professionals through the "Internet" [10-11]. Lectures by experts teach students to learn. In the Internet age, the teaching development of colleges and universities should be integrated with society and economy, especially in the financial management profession. It should constantly adapt to social needs and innovate education and teaching models.

\subsection{Optimize Resource Allocation}

Aiming at the problem of insufficient utilization of resources for network construction in the school, the author puts forward suggestions for cultivating financial management professionals to optimize resource allocation. To optimize the allocation of resources, it is necessary to start from two aspects, including the construction of teaching resources and the establishment of resource banks. Teaching resources should no longer be limited to traditional textbooks. Instead, some network information resources should be incorporated into students" learning resources, such as "microclasses", "MO Classes", "flipped classrooms", etc., in order to broaden students' learning channels, Expand students' learning resources. Students as the main body in the learning process, their independent learning ability and independent thinking ability are the basic requirements of school education, and the teaching resources such as "micro-classes" and "moo lessons" meet the needs and teaching requirements of students. In addition, the construction of basic equipment is the basis to ensure that these resources can be used by students. Therefore, in order to promote the development of financial management teaching in the "Internet + " era and cultivate excellent financial management professionals, schools should build a sound infrastructure and build a network. The teaching platform allows students to have the latest online teaching resources.

(1) Comprehensive training courses. Students can be divided into several groups. The group members are responsible for various job positions in the company, responsible for cashier, cost budgeting and other duties, and then compete with other groups in the market. This course allows students to have professional skills and teamwork ability. Application helps to improve the comprehensive quality of students.

(2) Skill competition. In order to stimulate students to master the practical skills of this major, skill competitions can be held regularly, such as: money counting competition, computerized competition, manual accounting competition, electronic sand table competition, etc. These competitions should be held for students in different academic years, so that the student's course progress can be matched with the competition content. The school can also organize students to participate in provincial and municipal professional competitions, allowing students to exercise themselves through a larger platform.

\subsection{Improve the Effectiveness of Off-campus Internships}

Off-campus internships can allow students to exercise their hands-on skills. Therefore, financial management accounting majors must conduct offcampus internships before entering the society. In order to improve the effectiveness of off-campus internships, colleges and universities should actively develop school-enterprise cooperation and establish a powerful practice. Training base. At the same time, according to some students' reports that off-campus internships have nothing to do with the work content, the school should try its best to increase the scale and grade of internship cooperative enterprises, while matching students' internship positions with their majors. In addition, reasonable time needs to be arranged so that students can exercise themselves outside the school without affecting the exam and study time. Finally, in order to encourage students to participate in off-campus internships, a scientific evaluation system should be established so that students can attach importance to internships. The details are as follows:

\subsubsection{Increase the Scale and Grade of Internship Cooperative Enterprises}

During the investigation of financial management students, it was found that most of the students wanted to enter large companies for internships. This is because the management of large companies should be more systematic, the work process should be more standardized, and the system should be relatively more robust. Under the environment, you can learn more professional knowledge. At the same time, large companies will also be more inclined to use computerized accounting software, which can help students access the latest financial management information. On the other hand, in some small businesses, students are in a situation where they can do internships for the company. At the same time, the survey found that some students were resistant to the off-campus internships arranged by the school, believing that the internships arranged by the school actually provided cheap labor for enterprises. Therefore, schools must pay attention to the scale and grade of cooperative enterprises, and choose cooperative enterprises for the purpose of cultivating financial management talents, rather than providing enterprises with cheap labor. 


\subsubsection{Reasonably Arrangement of Internship Time}

Some students stated that they did not want to participate in off-campus internships because the time is too tight and they cannot improve themselves through phased internships. According to the survey, students are dissatisfied with the internship time arranged by the school in these two aspects: First, the time period is short, mostly 15-30 days. The students have just gotten familiar with the business environment, adapted to the work content, and have not yet fully entered the working state. It's over. The second is the conflict between the internship time arranged by the school and the examination time. Many schools arrange the time in the first semester of the last school year, but this time period conflicts with the time of the student's entrance examination. In order to have more time for study, often they are not willing to participate in the internship arranged by the school. Therefore, these colleges and universities can arrange internships reasonably according to the students' conditions, and it is best to use the winter and summer vacations to arrange students to go out to study, so that the internship time will not be too short and will not delay the students' normal review preparation.

\subsubsection{Establish and Improve Effective Evaluation Mechanism}

In order to ensure that students can truly learn accounting practical skills during off-campus internships, colleges and universities should establish a scientific evaluation mechanism for students to score students' off-campus internships and incorporate their off-campus internship scores into their total scores. Pay attention to off-campus internships. Students' offcampus internship scores should include the following three parts: first, the evaluation of the internship unit, the internship situation of the student in the unit, the internship unit's master knows best, so there should be one item for the internship unit to score; Write the internship experience and summary, understand the students' internship results outside the school, and then score them. The third is to evaluate students' active learning awareness during the internship. During the students' off-campus internship, the school should be equipped with an instructor to provide remote guidance, so the students' behavior during the entire internship process, such as actively asking questions, should also be included in the evaluation system. In addition, colleges and universities must adjust the evaluation mechanism according to the situation of school internships, but in the evaluation process, they must be objective and impartial. In this way, students can recognize the results of internship evaluation and pay more attention to internship evaluation. The establishment of an evaluation mechanism is extremely important for enhancing the effectiveness of off-campus internships. Only by establishing a complete off-campus internship evaluation mechanism can students pay attention to internships and take internships seriously.

\section{CONCLUSIONS}

With the rapid development of information technology and the vigorous reform of education, the "Internet + " financial management talent training mode has become an inevitable trend. This is an inevitable requirement under the background of the global informatization, education reform and new curriculum standards. In this context, actively promote the integration of the Internet and professional talent training.

\section{ACKNOWLEDGMENTS}

(1)Liming Vocational University on Approving the Establishment of School-level General Projects in 2020 (Li Da [2020] No. 43) "University Network Ideological Security Related Issues and countermeasures research" (LAS202028)

(2)The thirteenth Five-year Plan of Fujian provincial Ministry of Education, Project of 2020. "Reach on the cultivation of "Craftsman Spirit" in undergraduate specialty teaching in colleges and universities" (FJJKCG20- 6)

(3)The 2020 Lifelong Education Research Project in Fujian Province "Research on the Construction of the Intelligent Elderly Care Service System in Fujian Community Based on the Concept of Lifelong Education-Taking Xiamen as an Example" (ZS20236)

(4)The 2020 academic research fund project of Xiamen Institute of Technology Business School

\section{REFERENCES}

[1] Pan G, Shankararaman V, Seow P S, et al. Designing an accounting analytics course using experiential learning approach $[\mathrm{J}]$. Accountancy Business and the Public Interest, 2017, 16: 1-23.

[2] Chen Jing, Zhao Junfeng. The professional development of college teachers under "Internet + education" $[\mathrm{J}]$. Educational Theory and Practice, 2016, 36(27):41-43.

[3] Vallascas F, Hagendorff J. The impact of European bank mergers on bidder defaultrisk [J]. Journal of Banking \& Finance, 2016,35(4):902-915.

[4] Tan Zhouchao. Research on the Cultivation of Enterprise Accounting Talents in Zhuzhou City [D]. Zhuzhou: Hunan University of Technology, 2018. 
[5] Wang Yan. Accounting Education Concept and Cultivation of Innovation Ability_-Based on the Perspective of Accounting Education for NonAccounting Majors in Economics and Management [J]. Accounting Research, 2016, 000(002): 89-94.

[6] Li Xiaohui. Research on Accounting Teaching System: Lessons from British Universities [J]. Accounting Research, 2009(10):79-84+97.

[7] Zhang Chunying, Feng Jianjun. On the design of the training model of accounting professionals [J]. China Higher Education, 2012, 000(017): 60-61.

[8] Wang Qingshi, Liu Wei, Sun Zongyang, et al. Research and Design of Cultivation Standards for Outstanding Accounting Talents at Undergraduate Level[J]. Educational Research, 2013(01):99-102.

[9] Zhang Qian, Huo Ying. Research on the Cultivation Model of Excellent Accounting Talents from the Perspective of Social Networks[J]. Finance and Accounting Newsletter, 2014(25):5051.

[10] Qin Rongsheng. The development trend of the accounting industry in the "Internet + " era [J]. Chinese Certified Public Accountant, 2015, 000(012): 20-24.

[11] Furfine C H, Rosen R J.Mergers increase default risk $[\mathrm{J}]$. Journal of Corporate Finance, 2015, 17(4):832-849. 